\title{
Use of 'Habit' is Not a Habit in Understanding Individual Technology Adoption: A Review of UTAUT2 based Empirical Studies
}

\begin{abstract}
The extended unified theory of acceptance and use of technology (UTAUT2) is the most comprehensive theory in examining individual acceptance and use of technology as on date. 'Habit' was the most important theoretical addition into UTAUT2 to challenge the role of behavioural intention as a lone predictor of technology use. However, a systematic review of 650 UTAUT2 citations revealed that only 147 studies utilised UTATU2 constructs and even if they utilised they did so in combination with external theories by omitting some of its original constructs with rare inclusion of moderators. Thus, this study aimed to understand the appropriateness of 'habit' among UTAUT2 based empirical studies. In doing so, this study found only 23 studies (35\%) that utilised 'habit' construct. Whereas the remaining 43 studies (65\%) did not utilise 'habit'. Researchers studying early stages of technology adoption in mandatory user settings should refrain from using habit construct. On the other hand, the usage of habit construct is encouraged in research to examine established technologies driven by consumer intrinsic motivation. The study also provide brief direction for practitioners and future research.
\end{abstract}

Keywords: Meta-analysis, Habit, Intrinsic motivation 


\section{Introduction}

Understanding why individuals accept or reject information technology (IT) is a mature stream in the contemporary information systems (IS) arena and constantly examined for two reasons: new technologies are rapidly evolving and finding their place both in organisations and society; and the IS failure rate continued to be high (Dwivedi et al., 2015). Unified theory of acceptance and use of technology (UTAUT) developed in the organisational context emphasising on the utilitarian value (extrinsic motivation) through exhaustive review, mapping and integration of constructs from eight dominant technology adoption models is the most comprehensive model in explaining individual technology acceptance and use (Venkatesh, Morris, Davis, \& Davis, 2003). The latest extended version of UTAUT popularly referred to as UTAUT2 comprises of three new constructs such as hedonic motivation, price value and habit focused on consumer context emphasising on hedonic value (intrinsic motivation) of technology users to be more relevant to emerging consumer technologies. However, in the UTAUT2, voluntariness of use was dropped as a moderator since consumers have no organisational mandate and in many situations, consumer behaviour is voluntary (Venkatesh, Thong, \& Xu, 2012). The predictive ability of UTAUT2 theory was much higher explaining about 74 percent of the variance in consumers' behavioural intention to use a technology and 52 percent of the variance in consumers' technology use (Venkatesh, Thong, \& Xu, 2016).

The UTAUT2 model has already garnered more than 2500 citations in Google Scholar alone despite its recent introduction in the year 2012, spanning from IS field and beyond emphasising on its predictive ability. However, systematic review of 650 UTAUT2 citations revealed 77\% of the studies cited UTAUT2 for generic purpose without employing its constructs whereas the remaining 23\% of studies, even if they utilised UTATU2, did so in combination with external theories omitting some of its original constructs with rare inclusion of moderators (Tamilmani, Rana, \& Dwivedi, 2017). 'Habit' was the most important new theoretical construct added into UTAUT2 model as a key predicator of technology use to challenge the role of behavioural intention as a lone predictor of technology use. To that extent habit as an key alternative mechanism in predicting consumer behaviour is lauded in the Journal of the Association for Information Systems (JAIS) special issue on the technology acceptance model (TAM) (Venkatesh et al., 2012). Thus, integrating 'habit' into the UTAUT2 will act as overarching mechanism and complement the focus of theory on intention as key driver of use behaviour. 'Habit' is function of both behavioural intention (BI) and use behaviour (UB) in the UTAUT2 model. HA $\rightarrow$ UB path was based on Habit/automaticity perspective (HAP) (Kim, Malhotra, \& Narasimhan, 2005), which states use behaviour occur automatically as a result of past habits without formation of evaluation and intention. Whereas, HA $\rightarrow$ BI path was based on the instant activation perspective (IAP) (Ajzen \& Fishbein, 2000) where use behaviour is considered as accelerated form of conscious use and perceived as function of behavioural intention such that past use habit will not weaken evaluation $\rightarrow$ intention $\rightarrow$ usage relationship.

Given the preceding discussion on centrality of habit construct as a key predicator of technology use and inconsistency among usage of UTAUT2 model on its entirety, the purpose of this study is to evaluate appropriateness of habit construct usage among UTAUT2 based studies. This study intends to achieve this through fulfilment of the following objectives:

- Identify studies that used UTAUT2 model as their underpinning theory and omitted 'habit' in their research model and reason for omission.

- Identify various antecedents/dependant variables of 'habit' and their significance among studies that utilized 'habit' from the UTAUT2 model. 
- To conduct meta-analysis of the empirical studies to understand the convergence and divergence of various 'habit' path relationships and their performance.

In doing so, this study aims to provide guidelines to future researchers on suitability of various context to operationalize 'habit' construct in their research model.

The next section of this paper i.e. Section 2 describes the research method employed in this study; Section 3 will present the findings of meta-analysis and narrative review of empirical studies on UTAUT2, which use 'habit' as a construct. This will be followed by discussion in Section 4 and conclusion in Section 5.

\section{Research Method}

This study employed combination of "narrative review”, “citation reference search” and "metaanalysis" approach to synthesize the existing research findings that operationalized 'habit' from the UTAUT2 model in understanding individual technology adoption (Dwivedi, Rana, Jeyaraj, Clement, \& Williams, 2017; King \& He, 2006; Venkatesh et al., 2016). Meta-analysis enables to establish true effect size of various relationships of population through accumulation of effect sizes from individual studies facilitated by statistical techniques (Dwivedi et al., 2017; Field, 2001; Grinstein, 2008; Wu \& Du, 2012). It allows to discover new knowledge that is undetectable otherwise in the isolated parcels of data scattered amongst individual "primary" studies (Schmidt, 1992). Cited reference search for Venkatesh et al.'s (2012) article in Scopus and Web of Science database from March 2012 to March 2017 resulted in 1,320 papers (823 from Scopus; 497 from Web of Science). On further scrutiny, it was identified that 452 citations were common in both databases resulting in 868 unique citations for UTAUT2. Out of 868 articles, 650 were fully downloadable and 147 utilized at least one UTAUT2 construct whereas the remaining 503 articles just citied UTAUT2 for generic reason (Tamilmani et al., 2017). Out of 147 studies, only 66 studies were empirical in nature to perform meta-analysis and hence the remaining studies were discarded from the scope of this research since they were neither empirical in nature nor did they report relevant data for meta-analysis. This leads us to the next stage of this study to screen 66 UTAUT2 based empirical studies to identify operationalization of 'habit' construct and appropriateness of its usage.

\section{Findings}

This section presents narrative review and meta-analysis findings of the 66 UTAUT2 based empirical studies based on the usage of habit construct. The findings resulted in classification of 66 studies broadly into two categories: 1) studies where 'habit' was not utilized - 43 studies; and 2) studies where 'habit' was utilized - 23 studies.

\subsection{Review of studies not using 'habit'}

Majority of the 66 UTAUT2 based empirical studies (i.e. 43) did not operationalize 'habit' in their research. Out of 43 studies that did not use 'habit' in their research model only 10 studies employed use behaviour (UB) (e.g. Alalwan, Dwivedi, \& Rana, 2017; Alalwan, Dwivedi, \& Williams, 2016) as their outcome variable with all of them utilizing behavioural intention (BI) 
as their immediate antecedent. Whereas BI was the most operated outcome variable with 31 studies hypothesizing BI (e.g. Slade, Dwivedi, Piercy, \& Williams, 2015; Wong, Tan, Tan, \& Ooi, 2015) as their final outcome variable. Finally, there were couple of studies that employed radically new outcome variables apart from BI and UB such as: 1) Location disclosure on location based social networking applications (Koohikamali, Gerhart, \& Mousavizadeh, 2015) and 2) Disclosure of information about others in social network sites (Koohikamali, Peak, \& Prybutok, 2017).

Table 1 presents findings of in-depth examination of these 43 studies across various contexts such as respondent types and system/technology examined to ascertain convergence and divergence among these studies. Eight broader themes emerged among 43 studies based on the system/technology examined. Mobile technologies emerged as the most studied theme with 20 studies empirically validating their research model without using 'habit' construct. Social networking sites emerged as the second most studied theme with five examinations. Whereas, five themes such as 1) Education, 2) Internet banking, 3) Music as a service, 4) Smart home devices and 5) Wearables jointly emerged as third most studied theme with two examinations each. Finally, the 'others category' involved eight studies that were not able be classified readily under any of the seven categories as seen form Table 1.

In terms of respondents, the researchers examined six different types of technological users across 43 studies. Consumers emerged as the most researched technological user type with as large as 25-research examination. 14 studies employed students as their respondent type to validate their research model on range of technology use. For instance, students were used as respondents to evaluate people willingness to pay for music as services (Wagner \& Hess, 2013) and information disclosure about others in social network sites to mention a few see Table 1 for exhaustive list. Finally, the remaining four respondents' types were examined on one instance each: 1) "Tourists" responses to mobile augmented reality travel guide (Kourouthanassis, Boletsis, Bardaki, \& Chasanidou, 2015); 2) “Citizens” adoption of egovernment (Lallmahomed, Lallmahomed, \& Lallmahomed, 2017); 3) “Teachers and Students" difference in the perspective of podcasting acceptance on campus (Lin, Zimmer, \& Lee, 2013); and 4) "Software developers" adoption intention to use existing software products (Stefi, 2015).

Table 1: Classification of studies not using habit construct

\begin{tabular}{|c|c|c|c|}
\hline SN & $\begin{array}{l}\text { Themes/ Technology Examined (With } \\
\text { Frequency) }\end{array}$ & $\begin{array}{l}\text { Respondents } \\
\text { Type (With } \\
\text { Frequency) }\end{array}$ & Citations \\
\hline 1 & \multicolumn{3}{|l|}{ Mobile Technologies (20) } \\
\hline & \multirow[t]{2}{*}{ Mobile Payments (7) } & Consumers (6) & $\begin{array}{l}\text { Jia, Hall, and Zhu (2015);Koenig- } \\
\text { Lewis, Marquet, Palmer, and Zhao } \\
\text { (2015); Oliveira, Thomas, Baptista, } \\
\text { and Campos (2016); Qasim and } \\
\text { Abu-Shanab (2016); Shaw (2014); } \\
\text { Slade et al. (2015) }\end{array}$ \\
\hline & & Students (1) & $\begin{array}{l}\text { Teo, Tan, Ooi, Hew, and Yew } \\
\text { (2015) }\end{array}$ \\
\hline & Smart phone adoption (3) & Consumers(3) & $\begin{array}{l}\text { Choudrie, Pheeraphuttharangkoon, } \\
\text { Zamani, and Giaglis (2014); Gao, } \\
\text { Krogstie, and Yang (2015); Gao, } \\
\text { Yang, and Krogstie (2015) }\end{array}$ \\
\hline
\end{tabular}




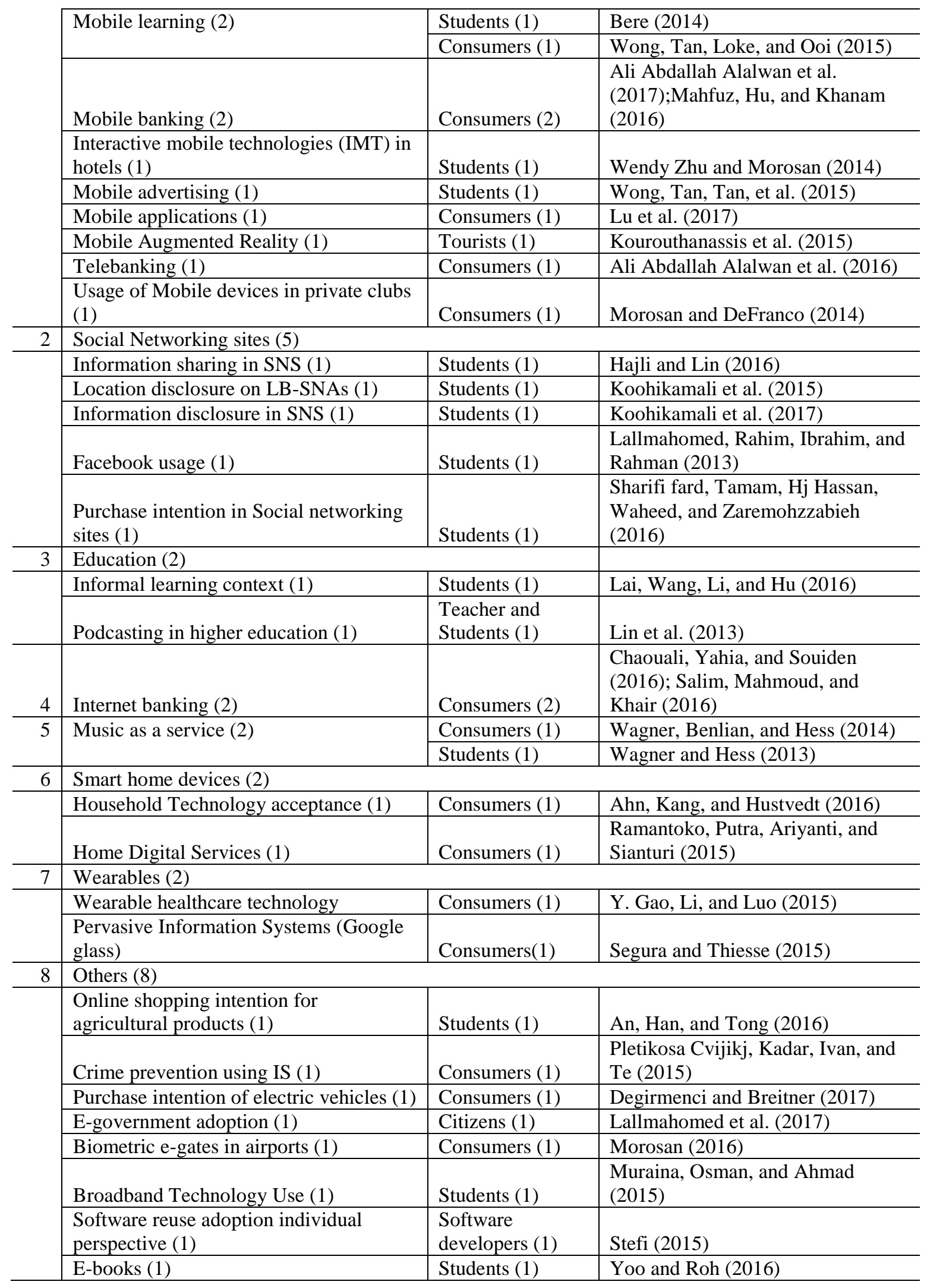




\subsection{Reason for studies not using 'habit'}

This section explains the reason behind 43 studies that adapted UTAUT2 as their underpinning theory for their research model without considering one of its core constructs 'habit'. Six categories emerged as reason for studies not using 'habit' construct seen from Table 2.

\subsubsection{No reason}

Majority of the studies (i.e. 29) fell under category 1. Studies under this category although utilized UTAUT2 as their underpinning theory and developed their model without 'habit', they did not provide any reason for omitting the construct from their research model. Such instances include but not limited to understanding determinants of students mobile learning technology acceptance and use in South Africa (Bere, 2014) and factors affecting consumers Internet banking implementation in Sudan (Salim et al., 2016).

Table 2: Reason for studies not using habit construct

\begin{tabular}{|c|c|c|c|}
\hline Category Type & Frequency & Description & Example Citations \\
\hline 1. No reason & 28 & $\begin{array}{l}\text { These studies did not } \\
\text { provide any reason for not } \\
\text { including habit in their } \\
\text { structural model }\end{array}$ & $\begin{array}{l}\text { Bere (2014); Hajli } \\
\text { and Lin (2016); } \\
\text { Salim et al. ; Slade et } \\
\text { al. (2015) }\end{array}$ \\
\hline 2. Early Adopters & 9 & $\begin{array}{l}\text { The users in this category } \\
\text { were at nascent stages of } \\
\text { adoption to technologies }\end{array}$ & $\begin{array}{l}\text { Ali Abdallah } \\
\text { Alalwan et al. } \\
\text { (2017); Ali Abdallah } \\
\text { Alalwan et al. } \\
\text { (2016); Oliveira et al } \\
\text { (2016); Ramantoko } \\
\text { et al. (2015) }\end{array}$ \\
\hline $\begin{array}{l}\text { 3. Recommended } \\
\text { for future Use }\end{array}$ & 3 & $\begin{array}{l}\text { Studies in this category } \\
\text { were cross sectional } \\
\text { among early stage users } \\
\text { of technology. }\end{array}$ & $\begin{array}{l}\text { Morosan and } \\
\text { DeFranco (2014); } \\
\text { Qasim and Abu- } \\
\text { Shanab (2016); } \\
\text { Wagner and Hess } \\
\text { (2013) }\end{array}$ \\
\hline 4. Prior experience & 1 & $\begin{array}{l}\text { This study used construct } \\
\text { similar to habit. }\end{array}$ & Lin et al. (2013) \\
\hline $\begin{array}{l}\text { 5. Habit extensively } \\
\text { studied }\end{array}$ & 1 & $\begin{array}{l}\text { Habit construct } \\
\text { extensively studied in this } \\
\text { research context. }\end{array}$ & Ahn et al. (2016) \\
\hline 6. Out of Scope & 1 & $\begin{array}{l}\text { This category perceived } \\
\text { habit construct as an } \\
\text { inappropriate context for } \\
\text { technology under } \\
\text { investigation. }\end{array}$ & Mahfuz et al. (2016) \\
\hline
\end{tabular}




\subsubsection{Early adopters}

Eight studies fell under the category of early adopters. Studies in this category did not use 'habit' since the technologies examined were relatively new and in introduction stage of the product life cycle with usage only among early adopters. In order for the consumers to generate habit for particular technology, it needed wider reach among users especially during growth stages of product life cycle. For instance, the study by Oliveira et al. (2016, p.406) on understanding consumer intention towards mobile payment in Portugal did not include 'habit' for the following reason:

"The habit construct was not included in the research model since mobile payment is a relatively new technology that has not yet gained sufficiently widespread use among consumers to generate a habit"

Whereas the study by Ramantoko et al. (2015, p.3) on exploring consumers behavioural intention to use home digital services in Indonesia omitted 'habit' stating the following reason:

“....the authors seek to understand characteristics in the early stage of adoption, where factor Habit was not taken into consideration. The authors' prejudice considers that Habit did not exist among the respondents during the time of study"

\subsubsection{Recommendation for future Use}

Three studies in this category mostly examined early stage of various technology users such as freemium usage of Music as a Services of students in Germany through cross sectional data collection (Wagner \& Hess, 2013). Wagner and Hess (2013, p.7) suggest 'habit' for the following reason:

"... results indicate that separating free and premium products can increase people's intention to use the premium version. However, lock-in effects resulting from the free version may also have a positive effect on users' willingness to pay. Future studies should therefore focus on habit and the resulting lock-in effect in detail."

Hence, future studies shall include 'habit' once researchers perceive users has formed habit for using particular technology through longitudinal study to examine user's continuous technological use.

\subsubsection{Prior experience}

The only study by Lin et al. (2013, p.420) in this category to understand difference in perspective of "Teachers and Students" podcasting acceptance on campus in Germany included construct similar to habit for the below reason:

“.....as an individual learns by doing, prior experiences with a technology is likely to impact perceptions of the amount of effort required to subsequently use the technology."

\subsubsection{Habit extensively studied}


The only study in this category by Ahn et al. (2016, p.83) examined consumers sustainable household technology acceptance in the USA and found 'habit' among extensively studied construct to justify their exclusion from their research model.

“.....household energy saving has been studied by environmental psychologists with the topics of motivations, behaviours, habits and interventions"

\subsubsection{Out of scope}

A final category with only one study by Mahfuz et al. (2016, p.432) omitted habit along with hedonic motion since they perceived both these constructs were out of scope of mobile banking adoption in their research of cultural dimensions and website quality influence on Consumers Mobile banking services in Bangladesh.

".....author omitted hedonic motivation and habit from the conceptual mode due not directly related to the mobile banking adoption..."

\subsection{Review of studies using 'habit'}

Unlike UTAUT2 based empirical studies that did not utilize 'habit', more than half of the studies that utilized 'habit' (i.e. 12 out of 23 studies) employed use behaviour as their outcome variable. Majority of the studies utilized 'habit' as an antecedent of use behaviour to research technologies in growth/mature stages of product life cycle rather than nascent stage and perceived users develop habit over a period for product utilization. Such instances include examining actual adopters habitual behaviour towards Internet banking adoption in Jordan (Alalwan, Dwivedi, Rana, Lal, \& Williams, 2015) and examination of students habitual use of learning management system in Malaysia that received limited attention (Ain, Kaur, \& Waheed, 2016). However, BI was operated as outcome variable only in eight studies with instances ranging from understanding consumers' Omni channel purchase intention behaviour in Spain (Juaneda-Ayensa, Mosquera, \& Murillo, 2016) to students usage of Facebook as learning tool in Spain (Escobar-Rodrguez, Carvajal-Trujillo, \& Monge-Lozano, 2014). Apart from BI and UB, three studies employed completely new outcome variables such as: 1) Job offer success (Buettner, 2016); 2) Consumerization (Dernbecher, Beck, \& Weber, 2013); and 3) Job seeker unemployment duration (Huang \& Chuang, 2016). Table 3 summarizes the various path relationships of 'habit' against various dependant variables, independent variables and moderators with their significance across 23 studies. Apart from being an antecedent on most instances, 'habit' also has few antecedents being a dependant variable.

\subsubsection{Habit as an antecedent}

Six dependant variables used 'habit' as their antecedent across the span of 23 studies. 'Habit' most frequently served as an antecedent of Behavioural Intention (BI) with 18 studies employing this relationship in examining a range of technology adoption. Out of 18 studies, 15 studies found the path relationship HA $\rightarrow$ BI to be significant (e.g. Alalwan et al., 2015; Ali, Nair, \& Hussain, 2016; Gonçalo Baptista \& Oliveira, 2015) whereas three studies (Ain et al., 2016; Juaneda-Ayensa et al., 2016; Raman \& Don, 2013) reported non-significant values for this path. Use Behaviour is the second most examined dependant variable with 13 studies utilizing 'habit' as its antecedent. The path relationship HA $\rightarrow$ UB reported significant results on 11 instances (Chong \& Ngai, 2013; Järvinen, Ohtonen, \& Karjaluoto, 2016; Nair, Ali, \& Leong, 2015) and the remaining two studies (Ain et al., 2016; Raman \& Don, 2013) reported non-significant path values. 
'Habit' is used as an antecedent of four other constructs apart from BI and UB, such as: 1) Performance expectancy (PE) in understanding consumer's intention to share user generated content in social network sites (Herrero \& San Martín, 2017), 2) Consumerization (CN) of information technology among European university students (Dernbecher et al., 2013), 3) Perceived relevance (PR) of Facebook as a social media learning platform (Escobar-Rodrguez et al., 2014), and 4) Degree of co-creation (DCC) in understating consumers co-creation of value in hotels using mobile devices (Morosan \& DeFranco, 2016). The path relationship was significant on all the four instances and need more examination in future to improve the validity. Age, gender, experience and social influence (SI) moderated the path relationships among the path $\mathrm{HA} \rightarrow \mathrm{BI}, \mathrm{HA} \rightarrow \mathrm{UB}$ and $\mathrm{HA} \rightarrow \mathrm{CN}$ on various combinations and found to be non-significant on all instance as seen from Table 3.

In the pursuit, to understand effect of consumers technology use habits on their continuous intention to use mobile payments the study of Jia, Hall, and Sun (2014) employed four different forms of consumer habits: 1) Mobile service usage habit (MSUH), 2) Mobile payment usage habit (MPUH), 3) Online shopping habit (OSH), and 4) Cell phone usage habit (CPUH). These four constructs had various path relationships between themselves and BI as seen from Table 3. Out of seven different paths, five were significant except for two paths between OSH $\rightarrow \mathrm{BI}$ and $\mathrm{CPUH} \rightarrow \mathrm{BI}$. Thus, consumers Online shopping habit and cell phone usage habit does not translate into their intention to use mobile payments (Jia et al., 2014).

Table 3: Summary of habit path relationships

\begin{tabular}{r|l|l|c|c|l|r|l}
\hline SN & I.V. & D.V.(Mod) & Total & Sig & Example Citations (Sig) & NS & Citations (NS) \\
\hline 1 & HA & BI & 18 & 15 & $\begin{array}{l}\text { Ali A Alalwan et al. (2015); } \\
\text { Ali et al. (2016); Gonçalo } \\
\text { Baptista and Oliveira (2015) }\end{array}$ & $3 \begin{array}{l}\text { Ain et al. (2016); } \\
\text { Juaneda-Ayensa et al. } \\
\text { (2016); Raman and Don } \\
\text { (2013) }\end{array}$ \\
\hline 2 & HA & UB & 13 & 11 & $\begin{array}{l}\text { Chong (2013); Järvinen et al. } \\
\text { (2016); Nair et al. (2015) }\end{array}$ & 2 & $\begin{array}{l}\text { Ain et al. (2016); } \\
\text { Raman and Don (2013) }\end{array}$ \\
\hline 3 & HA & BI (Gen) & 3 & 0 & None & 3 & $\begin{array}{l}\text { Goncalo Baptista, } \\
\text { Baptista, Oliveira, and } \\
\text { Oliveira (2017); } \\
\text { Ramírez-Correa, } \\
\text { Rondán-Cataluña, and } \\
\text { Arenas-Gaitán (2014); } \\
\text { Wong, Wei-Han Tan, } \\
\text { Loke, and Ooi (2014) }\end{array}$ \\
\hline 4 & HA & BI (Age) & 2 & 0 & None & 2 & $\begin{array}{l}\text { Goncalo Baptista et al. } \\
\text { (2017); Ramírez-Correa } \\
\text { et al. (2014) }\end{array}$ \\
\hline 5 & HA & BI (Exp) & 1 & 0 & None & 1 & $\begin{array}{l}\text { Ramírez-Correa et al. } \\
\text { (2014) }\end{array}$ \\
\hline 6 & HA & UB (Gen) & 2 & 0 & None & 2 & $\begin{array}{l}\text { Goncalo Baptista et al. } \\
\text { (2017); Ramírez-Correa } \\
\text { et al. (2014) }\end{array}$ \\
\hline 7 & HA & UB (Age) & 2 & 0 & None & 2 & $\begin{array}{l}\text { Goncalo Baptista et al. } \\
\text { (2017); Ramírez-Correa } \\
\text { et al. (2014) }\end{array}$ \\
\hline & & & & & & & $\begin{array}{l}\text { Ramírez-Correa et al. } \\
\text { (2014) }\end{array}$ \\
\hline
\end{tabular}




\begin{tabular}{|c|c|c|c|c|c|c|c|}
\hline 9 & HA & $\mathrm{PE}$ & 1 & 1 & $\begin{array}{l}\text { Herrero and San Martín } \\
\text { (2017) }\end{array}$ & 0 & None \\
\hline 10 & HA & $\mathrm{CN}$ & 1 & 1 & Dernbecher et al. (2013) & 0 & None \\
\hline 11 & HA & PR & 1 & 1 & $\begin{array}{l}\text { Escobar-Rodríguez and } \\
\text { Carvajal-Trujillo (2014) }\end{array}$ & 0 & None \\
\hline 12 & HA & $\mathrm{CN}(\mathrm{SI})$ & 1 & 0 & None & 1 & Dernbecher et al. (2013) \\
\hline 13 & HA & DCC & 1 & 1 & $\begin{array}{l}\text { Morosan and DeFranco } \\
\text { (2016) }\end{array}$ & 0 & None \\
\hline 14 & MSUH & BI & 1 & 1 & Jia et al. (2014) & 0 & None \\
\hline 15 & MPUH & BI & 1 & 1 & Jia et al. (2014) & 0 & None \\
\hline 16 & $\mathrm{OSH}$ & $\mathrm{BI}$ & 1 & 0 & None & 1 & Jia et al. (2014) \\
\hline 17 & CPUH & BI & 1 & 0 & None & 1 & Jia et al. (2014) \\
\hline 18 & $\mathrm{OSH}$ & MPUH & 1 & 1 & Jia et al. (2014) & 0 & None \\
\hline 19 & MSUH & MPUH & 1 & 1 & Jia et al. (2014) & 0 & None \\
\hline 20 & CPUH & MPUH & 1 & 1 & Jia et al. (2014) & 0 & None \\
\hline 21 & $\mathrm{EE}$ & HA & 1 & 1 & $\begin{array}{l}\text { Herrero and San Martín } \\
\text { (2017) }\end{array}$ & 0 & None \\
\hline 22 & SE & HA & 1 & 1 & Dernbecher et al. (2013) & 0 & None \\
\hline 23 & PI & HA & 1 & 1 & Dernbecher et al. (2013) & 0 & None \\
\hline 24 & NS & HA & 1 & 1 & $\begin{array}{l}\text { Morosan and DeFranco } \\
\text { (2016) }\end{array}$ & 0 & None \\
\hline 25 & HM & HA & 1 & 1 & $\begin{array}{l}\text { Herrero and San Martín } \\
\text { (2017) }\end{array}$ & 0 & None \\
\hline
\end{tabular}

[Legend: BI: Behavioural Intention; CN: Consumerization; CPUH: Cellphone usage habit; D.V.: Dependant Variable; DCC: Degree of co-creation; EE: Effort expectancy; Exp: Experience; Gen: Gender; HA: Habit; HM: Hedonic motivation; I.V.: Independent Variable; In. Sig: Number of insignificant path values; Mod: Moderator; MPUH: Mobile payment usage habit; MSUH: Mobile service usage habit; NS: Novelty seeking; OSH: Online shopping habit; PE: Performance Expectancy; PI: Personal Innovativeness; PR: Perceived relevance; SE: Selfefficacy; Sig: Number of significant path values; SN: Serial Number; UB: Use Behaviour]

\subsubsection{Antecedents of Habit}

There were also five antecedents for habit such as: 1) Novelty seeking (NS) in consumer value co-creation in hotels through mobile devices (Morosan \& DeFranco, 2016), 2) Effort expectancy (EE), 3) Hedonic motivation (HM) in evaluating consumer's intention to share user generated content in social network sites (Escobar-Rodrguez et al., 2014) and 4) Self-Efficacy (SE), 5) Personal Innovativeness (PI) in examining consumerization of IT (Dernbecher et al., 2013). The results of three studies found all five relationships of 'habit' and their antecedents to be significant.

\subsection{Meta-analysis of studies using habit construct}

Meta-analysis allows both significant and non-significant effects to be analysed through accumulation of various results taking the relative sample and effect size into consideration enabling more accurate and credible results due to the overarching span of the analysis (King \& He, 2006). This study conducted meta-analysis of various dependant, independent and moderating variables and their relationships with 'habit' explored in two or more times across 23 studies (e.g., King \& He, 2006; Rana, Dwivedi, \& Williams, 2015; Wu \& Du, 2012). Only six path relationships fulfilled this criterion and were eligible for meta-analysis. Table 4 presents summary on meta-analysis path coefficients $(\beta)$ results. 
Table 4: Meta-analysis of path coefficients ( $\beta$ ) involving 'habit' (Adapted from King \& He, 2006)

\begin{tabular}{|c|c|c|c|c|c|c|c|c|}
\hline SN & I.V. & D.V.(Mod) & \# & TSS & $p(E S)$ & Meta $(\beta)$ & $95 \% \mathrm{~L}(\beta)$ & $95 \% \mathrm{H}(\beta)$ \\
\hline 1 & HA & $\mathrm{BI}$ & 18 & 8501 & 0.000 & 0.276 & 0.186 & 0.362 \\
\hline 2 & HA & UB & 13 & 6820 & 0.000 & 0.273 & 0.157 & 0.382 \\
\hline 3 & HA & BI(Gen) & 3 & 1020 & 0.886 & -0.005 & -0.066 & 0.057 \\
\hline 4 & HA & BI(Age) & 2 & 827 & 0.213 & 0.043 & -0.025 & 0.111 \\
\hline 5 & HA & UB(Gen) & 2 & 827 & 0.975 & -0.001 & -0.069 & 0.067 \\
\hline 6 & HA & UB(Age) & 2 & 827 & 0.378 & 0.031 & -0.038 & 0.099 \\
\hline
\end{tabular}

[Legend: \#: Number of studies; D.V.: Dependant variable; Gen: Gender; H(r): Highest (beta); In. Sig ( $\beta$ ): Number of insignificant path values; I.V.: Independent Variable; L( $\beta$ ): Lowest (Beta); Meta( $\beta)$ : Meta-analysis path coefficient; Mod: Moderator; p(ES): Estimated value of p; TSS.: Total sample size]

The results revealed only two relationships using 'habit' as an antecedent, i.e. HA $\rightarrow \mathrm{BI}$ and $\mathrm{HA} \rightarrow$ UB emerged as significant relationships at $\mathrm{p}<0.001$ level. Whereas all the remaining four habit based relationships with behavioural intention and use behaviour moderated by age and gender were insignificant. $\mathrm{HA} \rightarrow \mathrm{BI}$ emerged as the strongest path with meta-analysis $(\beta)$ of 0.276 very closely followed by $\mathrm{HA} \rightarrow \mathrm{UB}$ with meta-analysis $(\beta)$ of 0.273 . The $95 \%$ confidence interval for $\mathrm{HA} \rightarrow \mathrm{BI}$ was the narrowest with Low $(\beta)-0.186$ and $\operatorname{High}(\beta)-0.362$, revealing the range is narrow enough to provide at least one confidence in the extent of variance that could be explained. Whereas 95\% confidence interval for HA $\rightarrow$ UB was bit wider with Low $(\beta)-0.157$ and High $(\beta)-0.382$.

\section{Discussion}

The purpose of this study was to have deeper understanding on appropriateness of the usage pf 'habit' among 66 empirical studies that used UTAUT2 as their underpinning theory in their research. The findings reveal that 43 studies (62\%) did not operationalize habit in their research model whereas 31 of the 43 studies (72\%) hypothesized BI as their outcome variable rather than UB. Habit is an outcome of consumers prolonged experience in using particular technology and strengthened as result of repeated behaviour (Limayem, Hirt, \& Cheung, 2007). Majority of the studies that did not utilize 'habit' were those that conducted their research on mobile technologies. The studies that omitted 'habit' dealt with technologies in introduction stage of product life cycle and felt consumers did not have enough experience to formulate habitual behaviour for technology under investigation. Thus, it was more appropriate for them to measure behavioural intention than use behaviour. However, consumers tend to form habit after using technology for prolonged period and 'habit' is a critical factor in predicting the use of technology rather than its initial acceptance (Kim et al., 2005; Limayem et al., 2007). This was quite evident as 13 out of 23 studies (52\%) that operationalized 'habit' in their research model employed use behaviour as their outcome variable against 10 out of 43 (23\%) non-habit related studies.

No reason emerged as the top category among studies that did not utilize 'habit' with 28 out of 43 studies (65\%) not providing any reason for exclusion. However, 12 out of remaining 15 studies excluded 'habit' mentioning technologies researched were in introduction stages used by early adopters and recommended it for future use. The reason for final three studies to exclude 'habit' were: 1) Use of prior experience as an alternative, 2) Habit extensively studied and 3) Habit was out of scope in the research context under investigation. Researchers should be cautious in using prior experience as a proxy to measure habit. Although experience in using technology is necessary to form habit, experience alone is not a sufficient condition for the formation of habit. Moreover, experience in using technology over passage of time can form 
differing level of habits among users depending upon user's familiarity and degree of interaction with target technology (Venkatesh et al., 2012).

In terms of studies used 'habit', it mostly served as antecedent of BI (18 studies) and UB (13 studies). The path relationships $\mathrm{HA} \rightarrow \mathrm{BI}$ and $\mathrm{HA} \rightarrow \mathrm{UB}$ were together found non-significant in three studies. Two of these non-significant studies were on mandatory settings rather than on voluntary settings such as: 1) Examination of student's use of learning management system (Ain et al., 2016) and 2) Students' acceptance of learning management software (Moodle) (Raman \& Don, 2013). The plausible reason for non-significant relationships of 'habit' in such mandatory settings could be because students might have performed educational activities out of compulsion and social pressure (Ain et al., 2016), which is driven by extrinsic motivation rather than intrinsic motivation. Performance expectancy (PE), Consumerization (CN), Perceived relevance (PR) and Degree of co-creation (DCC) the remaining four dependant variables of habit had one significant examination each.

Furthermore, meta-analysis results revealed only two 'habit' based relationships i.e. HA $\rightarrow$ BI and $\mathrm{HA} \rightarrow \mathrm{UB}$ to be significant at $\mathrm{p}<0.001$ level. This underscores the dominance of BI and UB as predictors in understanding consumer technology acceptance and use. However, all the four moderator relationships of habit with BI and UB were found to be non-significant in metaanalysis. This is a significant departure from the original UTAUT2 model of Venkatesh et al. (2012) that had significant results for moderators' (i.e. age, gender, experience) influence on $\mathrm{HA} \rightarrow \mathrm{BI}$ and HA $\rightarrow$ UB. To that extent Venkatesh et al. (2016, p.347) omitted the moderators' effects in their multi-level framework for measuring individual technology acceptance and use. They rather merged moderators into individual level contextual factors including user attributes and prescribed them to be used based on context (Venkatesh et al., 2016). Finally, 'habit' apart from being an antecedent to dependant variables also have antecedents of its own with allsignificant effects. The antecedents of 'habit' need further examination so that practitioners can leverage them in order to build habit among technological users.

\section{Conclusion}

This study aimed to understand appropriateness of the construct 'habit' among the UTAUT2 based empirical studies. The findings revealed 43 out of 66 studies did not operationalize 'habit' in their study with all of them focusing on introduction stage of product life cycle having early adopters as their users. Hence, 'habit' is not an appropriate construct in examining new to market technologies where sufficient time has not elapsed for users to develop habitual behaviour. In addition, 'habit' is not an appropriate construct in mandatory settings such as student's use of learning management system where they are compelled to use technology driven by extrinsic motivation. Moreover, the meta-analysis results confirmed the effects of moderators to be completely non-significant on 'habit' based relationships with its dependant variables. Future studies should be cautious in operationalizing 'habit' and their moderators in the above-mentioned scenarios. Further, studies should refrain from using experience as proxy for measuring 'habit'. Since experience is a necessary but not a sufficient condition to form 'habit'. However, 'habit' emerged as a very strong predictor of BI and UB. 'Habit' is a valid construct for studies to examine products after introduction stages in the voluntary settings driven through consumer intrinsic motivation. This study found five antecedents of 'habit' all having significant impact on it. Thus, future research should focus on the antecedents of 'habit' to understand their impact to develop it as a key predicator of technology use.

\section{References}


Ahn, M., Kang, J., \& Hustvedt, G. (2016). A model of sustainable household technology acceptance. International Journal of Consumer Studies, 40(1), 83-91.

Ain, N., Kaur, K., \& Waheed, M. (2016). The influence of learning value on learning management system use: An extension of UTAUT2. Information Development, 32(5), 1306-1321.

Ajzen, I., \& Fishbein, M. (2000). Attitudes and the attitude-behavior relation: Reasoned and automatic processes. European Review of Social Psychology, 11(1), 1-33.

Alalwan, A. A., Dwivedi, Y. K., \& Rana, N. P. (2017). Factors influencing adoption of mobile banking by Jordanian bank customers: Extending UTAUT2 with trust. International Journal of Information Management, 37(3), 99-110.

Alalwan, A. A., Dwivedi, Y. K., Rana, N. P., Lal, B., \& Williams, M. D. (2015). Consumer adoption of Internet banking in Jordan: Examining the role of hedonic motivation, habit, self-efficacy and trust. Journal of Financial Services Marketing, 20(2), 145-157.

Alalwan, A. A., Dwivedi, Y. K., \& Williams, M. D. (2016). Customers' intention and adoption of telebanking in Jordan. Information Systems Management, 33(2), 154-178.

Ali, F., Nair, P. K., \& Hussain, K. (2016). An assessment of students' acceptance and usage of computer supported collaborative classrooms in hospitality and tourism schools. Journal of Hospitality, Leisure, Sport \& Tourism Education, 18, 51-60.

An, L., Han, Y., \& Tong, L. (2016). Study on the Factors of Online Shopping Intention for Fresh Agricultural Products Based on UTAUT2. 2nd Information Technology and Mechatronics Engineering Conference.

Baptista, G., Baptista, G., Oliveira, T., \& Oliveira, T. (2017). Why so serious? Gamification impact in the acceptance of mobile banking services. Internet Research, 27(1), 118139.

Baptista, G., \& Oliveira, T. (2015). Understanding mobile banking: The unified theory of acceptance and use of technology combined with cultural moderators. Computers in Human Behavior, 50, 418-430.

Bere, A. (2014). Exploring determinants for mobile learning user acceptance and use: An application of UTAUT. 11th International Conference on Information Technology: New Generations (ITNG).

Buettner, R. (2016). Getting a job via career-oriented social networking sites: the weakness of ties. 49th Hawaii International Conference on System Sciences.

Chaouali, W., Yahia, I. B., \& Souiden, N. (2016). The interplay of counter-conformity motivation, social influence, and trust in customers' intention to adopt Internet banking services: The case of an emerging country. Journal of Retailing and Consumer Services, 28, 209-218.

Chong, A. Y.-L. (2013). A two-staged SEM-neural network approach for understanding and predicting the determinants of m-commerce adoption. Expert Systems with Applications, 40(4), 1240-1247.

Chong, A. Y.-L., \& Ngai, E. W. (2013). What Influences Travellers' Adoption of a Locationbased Social Media Service for Their Travel Planning? PACIS.

Choudrie, J., Pheeraphuttharangkoon, S., Zamani, E., \& Giaglis, G. (2014). Investigating the adoption and use of smartphones in the UK: A silver-surfers perspective.

Degirmenci, K., \& Breitner, M. H. (2017). Consumer purchase intentions for electric vehicles: Is green more important than price and range? Transportation Research Part D: Transport and Environment, 51, 250-260.

Dernbecher, S., Beck, R., \& Weber, S. (2013). Switch to your own to work with the known: An empirical study on consumerization of it. 
Dwivedi, Y. K., Rana, N. P., Jeyaraj, A., Clement, M., \& Williams, M. D. (2017). Reexamining the Unified Theory of Acceptance and Use of Technology (UTAUT): Towards a Revised Theoretical Model. Information Systems Frontiers, 1-16.

Dwivedi, Y. K., Wastell, D., Laumer, S., Henriksen, H. Z., Myers, M. D., Bunker, D., . . . Srivastava, S. C. (2015). Research on information systems failures and successes: Status update and future directions. Information Systems Frontiers, 17(1), 143-157.

Escobar-Rodrguez, T., Carvajal-Trujillo, E., \& Monge-Lozano, P. (2014). Factors that influence the perceived advantages and relevance of Facebook as a learning tool: An extension of the UTAUT. Australasian Journal of Educational Technology, 30(2).

Escobar-Rodríguez, T., \& Carvajal-Trujillo, E. (2014). Online purchasing tickets for low cost carriers: An application of the unified theory of acceptance and use of technology (UTAUT) model. Tourism Management, 43, 70-88.

Field, A. P. (2001). Meta-analysis of correlation coefficients: a Monte Carlo comparison of fixed-and random-effects methods. Psychological methods, 6(2), 161.

Gao, S., Krogstie, J., \& Yang, Y. (2015). Differences in the adoption of smartphones between middle aged adults and older adults in China. Paper presented at the International Conference on Human Aspects of IT for the Aged Population.

Gao, S., Yang, Y., \& Krogstie, J. (2015). The adoption of smartphones among older adults in China. International Conference on Informatics and Semiotics in Organisations.

Gao, Y., Li, H., \& Luo, Y. (2015). An empirical study of wearable technology acceptance in healthcare. Industrial Management \& Data Systems, 115(9), 1704-1723.

Grinstein, A. (2008). The relationships between market orientation and alternative strategic orientations: A meta-analysis. European Journal of Marketing, 42(1/2), 115-134.

Hajli, N., \& Lin, X. (2016). Exploring the security of information sharing on social networking sites: The role of perceived control of information. Journal of Business Ethics, 133(1), 111-123.

Herrero, Á., \& San Martín, H. (2017). Explaining the adoption of social networks sites for sharing user-generated content: A revision of the UTAUT2. Computers in Human Behavior, 71, 209-217.

Huang, K.-Y., \& Chuang, Y.-R. (2016). A task-technology fit view of job search website impact on performance effects: An empirical analysis from Taiwan. Cogent Business \& Management, 3(1), 1253943.

Järvinen, J., Ohtonen, R., \& Karjaluoto, H. (2016). Consumer Acceptance and Use of Instagram. 49th Hawaii International Conference on System Sciences.

Jia, L., Hall, D., \& Sun, S. (2014). The effect of technology usage habits on consumers' intention to continue use mobile payments.

Jia, L., Hall, D., \& Zhu, S. (2015). Trust building in consumer learning process and its effect on consumers' behavioral intention toward mobile payments.

Juaneda-Ayensa, E., Mosquera, A., \& Murillo, Y. S. (2016). Omnichannel customer behavior: key drivers of technology acceptance and use and their effects on purchase intention. Frontiers in psychology, 7.

Kim, S. S., Malhotra, N. K., \& Narasimhan, S. (2005). Research note-two competing perspectives on automatic use: A theoretical and empirical comparison. Information Systems Research, 16(4), 418-432.

King, W. R., \& He, J. (2006). A meta-analysis of the technology acceptance model. Information \& Management, 43(6), 740-755.

Koenig-Lewis, N., Marquet, M., Palmer, A., \& Zhao, A. L. (2015). Enjoyment and social influence: predicting mobile payment adoption. The Service Industries Journal, 35(10), 537-554. 
Koohikamali, M., Gerhart, N., \& Mousavizadeh, M. (2015). Location disclosure on LB-SNAs: The role of incentives on sharing behavior. Decision Support Systems, 71, 78-87.

Koohikamali, M., Peak, D. A., \& Prybutok, V. R. (2017). Beyond self-disclosure: Disclosure of information about others in social network sites. Computers in Human Behavior, 69, 29-42.

Kourouthanassis, P., Boletsis, C., Bardaki, C., \& Chasanidou, D. (2015). Tourists responses to mobile augmented reality travel guides: The role of emotions on adoption behavior. Pervasive and Mobile Computing, 18, 71-87.

Lai, C., Wang, Q., Li, X., \& Hu, X. (2016). The influence of individual espoused cultural values on self-directed use of technology for language learning beyond the classroom. Computers in Human Behavior, 62, 676-688.

Lallmahomed, M. Z., Lallmahomed, N., \& Lallmahomed, G. M. (2017). Factors influencing the adoption of e-Government Services in Mauritius. Telematics and Informatics, 34(4), 57-72.

Lallmahomed, M. Z., Rahim, N. Z. A., Ibrahim, R., \& Rahman, A. A. (2013). Predicting different conceptualizations of system use: Acceptance in hedonic volitional context (Facebook). Computers in Human Behavior, 29(6), 2776-2787.

Limayem, M., Hirt, S. G., \& Cheung, C. M. (2007). How habit limits the predictive power of intention: The case of information systems continuance. MIS Quarterly, 705-737.

Lin, S., Zimmer, J. C., \& Lee, V. (2013). Podcasting acceptance on campus: The differing perspectives of teachers and students. Computers \& Education, 68, 416-428.

Mahfuz, M. A., Hu, W., \& Khanam, L. (2016). The Influence of Cultural Dimensions and Website Quality on m-banking Services Adoption in Bangladesh: Applying the UTAUT2 Model Using PLS. WHICEB.

Morosan, C. (2016). An empirical examination of US travelers' intentions to use biometric egates in airports. Journal of Air Transport Management, 55, 120-128.

Morosan, C., \& DeFranco, A. (2014). When tradition meets the new technology: An examination of the antecedents of attitudes and intentions to use mobile devices in private clubs. International Journal of Hospitality Management, 42, 126-136.

Morosan, C., \& DeFranco, A. (2016). Co-creating value in hotels using mobile devices: A conceptual model with empirical validation. International Journal of Hospitality Management, 52, 131-142.

Muraina, I. D., Osman, W. R. B. S., \& Ahmad, A. (2015). The Roles of Some Antecedents of Broadband User Behavioural Intention among Students in the Rural Areas through PLS-SEM. American Journal of Applied Sciences, 12(11), 820.

Nair, P. K., Ali, F., \& Leong, L. C. (2015). Factors affecting acceptance \& use of ReWIND: Validating the extended unified theory of acceptance and use of technology. Interactive Technology and Smart Education, 12(3), 183-201.

Oliveira, T., Thomas, M., Baptista, G., \& Campos, F. (2016). Mobile payment: Understanding the determinants of customer adoption and intention to recommend the technology. Computers in Human Behavior, 61, 404-414.

Pletikosa Cvijikj, I., Kadar, C., Ivan, B., \& Te, F. (2015). Prevention or Panic: Design and Evaluation of a Crime Prevention IS.

Qasim, H., \& Abu-Shanab, E. (2016). Drivers of mobile payment acceptance: The impact of network externalities. Information Systems Frontiers, 18(5), 1021-1034.

Raman, A., \& Don, Y. (2013). Preservice teachers' acceptance of learning management software: An application of the UTAUT2 model. International Education Studies, 6(7).

Ramantoko, G., Putra, G., Ariyanti, M., \& Sianturi, N. V. (2015). Early Adoption Characteristic of Consumers': A Behavioral Intention to Use Home Digital Services in Indonesia. 
Ramírez-Correa, P. E., Rondán-Cataluña, F. J., \& Arenas-Gaitán, J. (2014). An empirical analysis of mobile Internet acceptance in Chile. Information Research, 19(3), 19-13.

Rana, N. P., Dwivedi, Y. K., \& Williams, M. D. (2015). A meta-analysis of existing research on citizen adoption of e-government. Information Systems Frontiers, 17(3), 547-563.

Salim, B. F., Mahmoud, M. H., \& Khair, H. M. PERCEIVED FACTORS AFFECTING THE INTERNET BANKING IMPLEMENTATION IN SUDAN: AN APPLICATION OF (UTAUT2).

Schmidt, F. L. (1992). What do data really mean? Research findings, meta-analysis, and cumulative knowledge in psychology. American Psychologist, 47(10), 1173.

Segura, A. S., \& Thiesse, F. (2015). Extending UTAUT2 to Explore Pervasive Information Systems. Paper presented at the ECIS.

Sharifi fard, S., Tamam, E., Hj Hassan, M. S., Waheed, M., \& Zaremohzzabieh, Z. (2016). Factors affecting Malaysian university students' purchase intention in social networking sites. Cogent Business \& Management, 3(1), 1182612.

Shaw, N. (2014). The mediating influence of trust in the adoption of the mobile wallet. Journal of Retailing and Consumer Services, 21(4), 449-459.

Slade, E. L., Dwivedi, Y. K., Piercy, N. C., \& Williams, M. D. (2015). Modeling consumers' adoption intentions of remote mobile payments in the United Kingdom: extending UTAUT with innovativeness, risk, and trust. Psychology \& Marketing, 32(8), 860-873.

Stefi, A. (2015). Do Developers Make Unbiased Decisions?-The Effect of Mindfulness and Not-Invented-Here Bias on the Adoption of Software Components. Paper presented at the ECIS.

Tamilmani, K., Rana, N. P., \& Dwivedi, Y. K. (2017). A Systematic Review of Citations of UTAUT2 Article and Its Usage Trends. Paper presented at the Conference on eBusiness, e-Services and e-Society.

Teo, A.-C., Tan, G. W.-H., Ooi, K.-B., Hew, T.-S., \& Yew, K.-T. (2015). The effects of convenience and speed in m-payment. Industrial Management \& Data Systems, 115(2), 311-331.

Venkatesh, V., Morris, M. G., Davis, G. B., \& Davis, F. D. (2003). User acceptance of information technology: Toward a unified view. MIS Quarterly, 425-478.

Venkatesh, V., Thong, J. Y., \& Xu, X. (2012). Consumer acceptance and use of information technology: extending the unified theory of acceptance and use of technology. MIS Quarterly, 36(1), 157-178.

Venkatesh, V., Thong, J. Y., \& Xu, X. (2016). Unified Theory of Acceptance and Use of Technology: A Synthesis and the Road Ahead. Journal of the Association for Information Systems, 17(5), 328.

Wagner, T. M., Benlian, A., \& Hess, T. (2014). Converting freemium customers from free to premium - the role of the perceived premium fit in the case of music as a service. Electronic Markets, 24(4), 259-268.

Wagner, T. M., \& Hess, T. (2013). What Drives Users to Pay for Freemium Services? Examining People's Willingness to Pay for Music Services.

Wendy Zhu, W., \& Morosan, C. (2014). An empirical examination of guests' adoption of interactive mobile technologies in hotels: Revisiting cognitive absorption, playfulness, and security. Journal of Hospitality and Tourism Technology, 5(1), 78-94.

Wong, C.-H., Tan, G. W.-H., Loke, S.-P., \& Ooi, K.-B. (2015). Adoption of mobile social networking sites for learning? Online Information Review, 39(6), 762-778.

Wong, C.-H., Tan, G. W.-H., Tan, B.-I., \& Ooi, K.-B. (2015). Mobile advertising: the changing landscape of the advertising industry. Telematics and Informatics, 32(4), 720-734.

Wong, C.-H., Wei-Han Tan, G., Loke, S.-P., \& Ooi, K.-B. (2014). Mobile TV: a new form of entertainment? Industrial Management \& Data Systems, 114(7), 1050-1067. 
Wu, J., \& Du, H. (2012). Toward a better understanding of behavioral intention and system usage constructs. European Journal of Information Systems, 21(6), 680-698. 